\title{
1995 and 1996 Upper Three Runs Dye Study Data Analyses
}

by

K. F. Chen

Westinghouse Savannah River Company

Savannah River Site

Aiken, South Carolina 29808

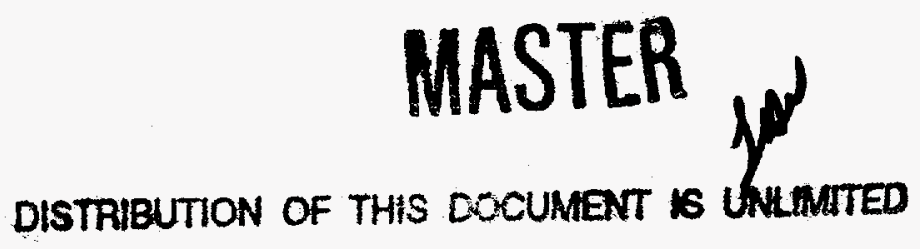

DOE Contract No. DE-AC09-96SFi18500

This paper was prepared in connection with work done under the above contract number with the U.S.

Department of Energy. By acceptance of this paper, the publisher and/or recipient acknowledges the U.S. Government's right to retain a nonexclusive, royalty-free license in and to any copyright covering this paper, along with the right to reproduce and to authorize others to reproduce all or part of the copyrighted paper. 


\title{
1995 and 1996 Upper Three Runs Dye Study Data Analyses (U)
}

\author{
Kuo-Fu Chen
}

Savannah River Technology Center

Publication Date: June 1998

DOES NOT CONTAIN

UNCLASSIFIED CONTROLLED NUCLEAR INFORMATION

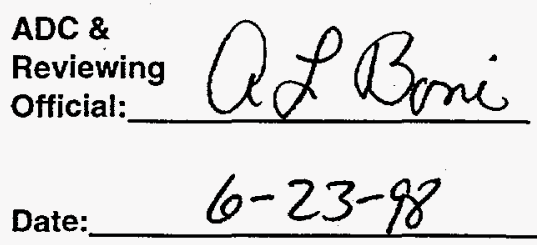

\section{Westinghouse Savannah River Company Savannah River Site Aiken, SC 29808}

This document was prepared in connection with work done under Contract No. DE-AC09-96SR18500 with the U. S. Department of Energy 


\section{DISCLAIMER}

This report was prepared as an account of work sponsored by an agency of the United States Government. Neither the United States Government nor any agency thereof, nor any of their employees, makes any wairtanty, express or implied, or assumes any legal liability or responsibility for the accuracy, completeness, or usefulness of any information, apparatus, product, or process disclosed, or represents that its use would not infringe privately owned rights. Reference herein to any specific commercial product, process, or service by trade name, trademark, manufacturer, or otherwise does not necessarily constitute or imply its endorsement, recommendation, or favoring by the United States Government or any agency thereof. The views and opinions of authors expressed herein do not necessarily state or reflect those of the United States Government or any agency thereof.

This report has been reproduced directly from the best available copy.

Available to DOE and DOE contractors from the Office of Scientific and Technical Information, P.O. Box 62, Oak Ridge, TN 37831; prices available from (615) 576-8401.

Available to the public from the National Technical Information Service, U.S. Department of Commerce; 5285 Port Royal Road, Springfield, VA 22161. 


\section{DISCLAIMER}

Portions of this document may be illegible electronic image products. Images are produced from the best available original document. 
WSRC-TR-98-00225

June 1998

DOCUMENT:

TITLE:
WSRC-TR-98-00225

1995 and 1996 Upper Three Runs Dye Study Data Analyses (U)

TASK:

TECHNICAL REVIEW

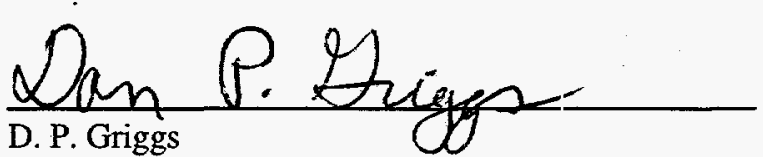

Date: $6 / 18 / 98$

SRTC/Measurement Technology Depar:ment/Nonproliferation Technologies Section

APPROVALS

R.P. Hd dis

Date: $6 / 22 / 98$

R. P. Addie, Manager, ATG

SRTC/Measurement Technology Department/Nonproliferation Technologies Section

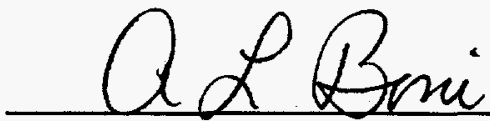

Date: $6-23-98$

A. L. Boni, Manager

SRTC/Measurement Technology Department/Nonproliferation Technologies Section

iii 
WSRC-TR-98-00225

June 1998

(Blank Page) 
WSRC-TR-98-00225

June 1998

ABSTRACT

This report presents an analysis of dye tracer studies conducted on Upper Three Runs. The revised STREAM code was used to analyze these studies and derive a stream velocity and a dispersion coefficient for use in acueous transport models. These models will be used to facilitate the establishment of aqueous effluent limits and provide contaminant transport information to emergency management in the event of a release. 
WSRC-TR-98-00225

June 1998

(Blank Page) 
WSRC-TR-98-00225

June 1998

\section{TABLE OF CONTENTS}

1. Summary

2. Introduction

3. 1995 Dye Study

4. Revised STREAM Code Modeling

5. Model Results for the 1995 Upper Three Runs Dye Study

6. 1996 Dye Study

7. Model Results for the 1996 Upper Three Runs Dye Study

8. Conclusions

9. References 


\section{LIST OF TABLES}

Table 1. Total Dye Mass Passing the Sampling Stations for the 1995 Upper Three Runs Dye Tracer Study

Table 2. Total Dye Mass Passing the Sampling Stations for the 1996 Upper Three Runs Dye Tracer Study

Table 3. Distance from the Sampling Locations to the Highway 278 Bridge

Table 4. Model Comparison for the 1995 Upper Three Runs Dye Study

Table 5. Model Comparison for the 1996 Upper Three Runs Dye Study 


\section{LIST OF FIGURES}

Figure 1. Dye Sampling Locations for 1995 and 1996 Dye Tracer Studies

Figure 2. Model Schematics (not to scale)

Figure 3. Model Simulation for 1995 Upper Three Runs Dye Study (Dye Concentrations at Road 8.1)

Figure 4. Model Simulation for 1995 Upper Three Runs Dye Study (Dye

Concentrations at Road 2.1)

Figure 5. Model Simulation for 1995 Upper Three Runs Dye Study (Dye Concentrations at Road F)

Figure 6. Model Simulation for 1995 Upper Three Runs Dye Study (Dye Concentrations at Road C)

Figure 7. Model Simulation for 1996 Upper Three Runs Dye Tracer Study (Dye Concentration at Road C)

Figure 8. Model Simulation for 1996 Upper Three Runs Dye Tracer Study (Dye Concentration at Hlighway 125)

Figure 9. Model Simulation for 1996 Upper Three Runs Dye Tracer Study (Dye Concentration at Box Landing)

Figure 10. Model Simulation for 1996 Upper Three Runs Dye Tracer

Study (Dye Concentration at Mouth) 
(Blank Page) 


\section{Summary}

This report presents an analysis of dye tracer studies conducted on Upper Three Runs. The revised STREAM code was used to analyze these studies and derive a stream velocity and a dispersion coefficient for use in aqueous transport models. These models will be used to facilitate the establishment of aqueous effluent limits and provide contaminant transport information to emergency management in the event of a release.

Dye tracer studies were conducted on Upper Three Runs on May 16, 1995, and May 9, 1996. The STREAM code analysis of the first study showed that the first sampling location at Treadway Bridge was too close to the dye release point (the Highway 278 bridge) to allow complete mixing of dye in the cross-sectional direction. The predicted peak concentrations for the 1996 dye study are significantly lower than the measured concentrations. This discrepancy can be attributed to errors in either the dye sample measurements or the calibration standards. It is recommended that the 1996 dye study be repeated with the sampling interval reduced from 60 minutes to 15 minutes.

\section{Introduction}

Radioactive and/or toxic materials in aqueous effluents may be released from SRS facilities into the Savannah River, either routinely or accidentally, through onsite streams. The facility effluent limits are set to minimize the exposure of the downstream population to levels 'As Low As Reasonably Achievable' (ALARA) during normal operation and accident events. A realistic aqueous transport model is required 1) to facilitate the establishment of aqueous effluent limits, and 2) to provide contaminant transport information to emergency management in the event of a release.

The major parameters of the surface water transport model are velocity and dispersion, which accounts for the effects of turbulent mixing. The dispersion coefficient is flowand stream-specific and is measured using dye tracer studies.

Two dye tracer studies were conducted on Upper Three Runs to measure stream-specific dispersion coefficients and flow velocities. Two separate tests were required because dye tracer introduced in the upper part of Upper Three Runs may become too dispersed to determine concentration centroids by the time the dye reaches the lower part of this stream. In the first test, dye was released on May 15, 1995, at the Highway 278 bridge to study the flow characteristics of the upper segment of Upper Three Runs. In the second test, which focused on the lower segment of this stream, dye was released on May 8, 1996, near Road C. The revised STREAM code $^{1}$ was used to analyze data from both tests. Descriptions of each test and the STREAM code model follow. 


\section{1995 Dye Study}

At 8:00 am on May 16, 1995, $1.8371 \mathrm{~kg}$ of Rhodamine WT were introduced into Upper Three Runs at the Highway 278 bridge. Dye concentration transients were measured at Road 8.1 (Treadway Bridge), Road 2.1 (Tyler Bridge), Road F, and Road C. Figure 1 shows the sampling locations. Reference 2 presents data from this study.

The principle of mass conservation was used to analyze the measured dye concentrations reported in Reference 2 . The rnass conservation equation is expressed as:

$$
M_{\text {released }}=\int_{T_{1}}^{T_{2}} Q_{i}(t) C_{i}(t) d t+\text { loses }
$$

where

$M_{\text {released }}=$ dye released

$Q_{i}(t) \quad=$ volumetric flow rate at sampling station $i$ and at time $t$

$C_{i}(t) \quad=$ dye concentration at sampling station $i$ and at time $t$

$T_{1}=$ time when the leading edge of the dye concentration profile arrives at the sampling station

$T_{2}=$ time when the tail of the dye concentration profile leaves the sampling station

losses $\quad=$ dye lost during transport

Equation 1 assumes that the dye is uniformly mixed over the cross-section flow area.

Table 1 compares calculated amounts of dye passing by the sampling stations with the measured amount of dye that was released at the Highway 278 bridge. As this table shows, the amounts calculated by integrating transient concentration profiles are less than the amount released, $1.8371 \mathrm{~kg}$, except at Treadway Bridge, where the calculated amount of dye was $2.7372 \mathrm{~kg}$. This disparity indicates that dye was not uniformly mixed at Treadway Bridge, probably due to its proximity to the release point. Treadway Bridge is only $1875 \mathrm{~m}$ ( $1.16 \mathrm{mile})$ downstream from the Highway 278 bridge.

\section{Revised STREAM Code Modeling}

The revised STREAM code, which is part of the SRTC WIND system, was used to predict downstream dye concentrations for the Upper Three Runs dye studies. The following sections describe the geometry, flow conditions, time step criterion, dispersion model, and source term used by the code. 


\section{Model Geometry}

Upper Three Runs is the longest of the site streams and is the only stream with headwaters arising outside the site. Tinker Creek flows into Upper Three Runs $4 \mathrm{~km}$ downstream from Tyler Bridge (Road 2.1). To analyze the dye study, only Upper Three Runs needs to be modeled. However, this model will be incorporated into the emergency response system to predict the pollutant transport down to the city of Savannah. Therefore, the river system model includes both Upper Three Runs and the Savannah River. The reach from Point 1 to Point 2 in Figure 1 was divided into 19 segments, each with a crosssectional area of $11.04 \mathrm{~m}^{2}$. The reach from Point 2 to Point 3 was divided into 42 segments, each with a cross-sectional area of $30.00 \mathrm{~m}^{2}$. The Savannah River from 30.5 $\mathrm{km}$ downstream from the New Savannah Bluff Lock and Dam to $14.5 \mathrm{~km}$ upstream from Fort Pulaski was divided into 4.89 segments, each with a cross-sectional area of $278 \mathrm{~m}^{2}$. All model segments are $500 \mathrm{~m}$ in length. The cross-sectional areas of Upper Three Runs were estimated from USGS measurements. The cross-sectional area for the Savannah River is obtained from previous 1990 and 1991 EPA dye studies 1 . Figure 2 depicts the schematic for the finite difference model. Table 3 lists the distances of the sample stations from the Highway 278 bridge.

\section{Flow Conditions}

The required inlet conditions are the Savannah River flow at Segment 1, the Upper Three Runs flow at Segment 54, and the Tinker Creek flow at Segment 73. Daily averaged flows from May 16, 1995, to May 19, 1995, for the Savannah River, Upper Three Runs, and Tinker Creek were obtained from U.S. Geological Survey Water Resources Data in South Carolina ${ }^{3}$.

\section{Time Step}

The time step was chosen to meet the numerical stability (Courant stability) criterion. The time step used was 0.0064 day (9.2 minutes), corresponding to a Courant stability parameter $\left(\frac{U_{x} \Delta t}{\Delta x}\right)$ of less than 0.66 . The variables in this parameter, $U_{x,}, \Delta t$, and $\Delta x$, are flow velocity, time step, and segment size, respectively. The estimated flow velocities from the USGS records during the dye study were $0.6 \mathrm{~m} / \mathrm{sec}$ for the Savannah River, 0.27 $\mathrm{m} / \mathrm{sec}$ for the upper part of Upper Three Runs, and $0.2 \mathrm{~m} / \mathrm{sec}$ for the lower part of Upper Three Runs. 


\section{Longitudinal Dispersion Coefficients}

The longitudinal dispersion coefficient was adjusted so that the predicted concentration distributions match those of the 1995 dye study data. The input dispersion coefficients are $0.0 \mathrm{~m}^{2} / \mathrm{sec}$ for the upper part of Upper Three Runs, $1.5 \mathrm{~m}^{2} / \mathrm{sec}$ for the lower part of Upper Three Runs, and $15 \mathrm{~m}^{2} / \mathrm{sec}$ for the Savannah River. The Savannah River dispersion coefficient was obtained from previous 1990 and 1991 EPA dye studies ${ }^{1}$. The effective dispersion coefficients used in the STREAM code also include the inherent numerical diffusion coefficients, $\left(\frac{U_{x} \Delta x}{2}\left(1-\frac{U_{x} \Delta t}{\Delta x}\right)\right)$, for the backward finite difference method, which are estimated to be $47.4 \mathrm{~m}^{2} / \mathrm{sec}$ for the upper part of Upper Three Runs, $39 \mathrm{~m}^{2} / \mathrm{sec}$ for the lower part of. Upper Three Runs, and $51 \mathrm{~m}^{2} / \mathrm{sec}$ for the Savannah River. Thus, the effective dispersion coefficients for the STREAM code model are $47.4 \mathrm{~m}^{2} / \mathrm{sec}$ for the upper part of Upper Three Runs, $40.5 \mathrm{~m}^{2} / \mathrm{sec}$ for the lower part of Upper Three Runs, and $66 \mathrm{~m}^{2} / \mathrm{sec}$ for the Savannah River.

\section{$\underline{\text { Source Term }}$}

\section{$1.8371 \mathrm{~kg}$ of dye was instantaneously released at Segment 57.}

\section{Model Results for the 1995 Upper Three Runs Dye Study}

Figures 3 through 6 depict the calculated and measured dye concentration transients at Treadway Bridge (Road 8.1), Tyler Bridge (Road 2.1), Road F, and Road C. The calculated peak concentration at Treadway Bridge is $84 \%$ less than the measured peak concentration, as shown in Table 4. This large error is caused by the fact that the sampling location at Treadway Bridge is too close the dye release point (Highway 278 Bridge) to allow complete mixing of dye in cross sectional direction. As the subsequent figures show, the calculated peak concentrations at the other sampling stations differed from the measured peak concentrations by -8 to $+15 \%$ and the calculated peak concentration travel times differed from the measured times by -1 to $-25 \%$.

\section{1996 Dye Study}

At 08:00 on May 9, 1996, $1.8371 \mathrm{~kg}$ of Rhodamine WT were released into Upper Three Runs near the Road C bridge, above the thermal lab. Dye concentrations were measured at Road C, Highway 125, Box Landing Road, and at the mouth of Upper Three Runs where it enters the Savannah River. Figure 1 shows the sampling locations. Dye sampling began at 08:00 on May 9, 1996, and ended at 11:30 on May 11, 1996. The 
fluorescence calibration standards were prepared on May 8, 1996. Laboratory sample analyses were delayed until the week of May 27, 1996 due to other priorities for the field operation personnel. Laboratory fluorometric analyses were completed on May 31, 1996. Reference 4 presents results from this study.

Table 2 compares the amounts of dye calculated by integrating the dye concentration transient at each sampling station with the measured amount of dye that was released. As this table shows, the calculated amounts of dye at the sampling stations are 3.4 times higher than the amount released. Physically, the dye concentrations at downstream sampling stations should be uniformly mixed in lateral and vertical directions. This indicates that something might have occurred to the samples or the calibration standards when they were left in the lab for 16 days.

\section{Model Results for the 1996 Upper Three Runs Dye Study}

The model used to analyze the 1995 Upper Three Runs dye study was identical to that used to analyze the 1996 Upper Three Runs dye study except for the flows and the dye release point. The flows 5 and the dye release point were modified to reflect the 1996 dye study conditions.

The model results are presented in Table 5 and Figures 7 through 10. The predicted peak concentrations at the sampling locations are significantly lower than the measured concentrations. This large discrepancy probably can be attributed to errors in the dye sample or the calibration standard concentrations, as mentioned previously.

\section{Conclusions}

The revised STREAM code was used to model the 1995 and 1996 Upper Three Runs dye studies. Tables 1 and 2 show, for each sampling stations, the time-integrated measured dye mass. The sampling location at Treadway Bridge was too close the dye release point (the Highway 278 Bridge) to allow complete mixing of dye in the cross-sectional direction. The predicted peak concentrations for the 1996 dye study are significantly lower than the measured concentrations. This large discrepancy probably results from errors in the dye sample measurements or the calibration standards. It is recommended that the 1996 dye study be repeated, with the sampling time interval reduced from 60 minutes to 15 minutes. 
9. References

1. Kuo-Fu Chen, "Revised Stream Code and WASP5 Benchmark (U)," WSRC-RP-95598, May 1995.

2. D.L. Dunn, "Upper Segments Upper Three Runs Dye Tracer Study - May 16, 1995," SRTC-ETS-95344, June 21, 1995.

3. T.W. Cooney, et al., "Water Resources Data South Carolina Water Year 1995," U.S. Geological Survey Water-Data Report SC-95-1.

4. A.L. Schwartzman and D.L. Dunn, "A Dye Tracer Study for the Lower Segments of Upper Three Runs - May 9th and June 6th, 1996," SRT-ESS-96-341, July 22, 1996.

5. T.W. Cooney, et al., "Water Resources Data South Carolina Water Year 1996," U.S. Geological Survey Water-Data Report SC-96-1. 
Table 1

Total Dye Mass Passing the Sampling Stations for the 1995 Upper Three Runs Dye Tracer Study

Sampling Station

Treadway Bridge (Road 8.1)

Tyler Bridge (Road 2.1)

Road F

Road C

\begin{tabular}{cc}
\multicolumn{2}{c}{ Time Integrated Dye Mass } \\
\hline $\mathrm{kg}$ & \% of Dye Mass Released \\
2.7372 & 149.00 \\
1.5884 & 86.46 \\
1.6029 & 87.25 \\
1.4824 & 80.69
\end{tabular}

Table 2

Total Dye Mass Passing the Sampling Stations for the 1996 Upper Three Runs Dye Tracer Study

Sampling Station

Road C

Highway 125

Box Landing Road

Mouth

\begin{tabular}{cc}
\multicolumn{2}{c}{ Time Integrated Dye Mass } \\
\hline $\mathrm{kg}$ & \% of Dye Mass Released \\
6.0051 & 326.88 \\
6.2312 & 339.19 \\
5.9246 & 322.50 \\
6.8120 & 370.80
\end{tabular}

Table 3

Distance from the Sampling Locations to the Highway 278 Bridge

Location

Distance (m)

Highway 278

Treadway Bridge (Road 8.1)

$$
\begin{array}{r}
0 \\
1875 \\
4029 \\
9564 \\
15397 \\
23525 \\
25678 \\
28548
\end{array}
$$


Table 4

Model Comparison for the 1995 Upper Three Runs Dye Study

$\underline{\text { Sample Location }}$

\begin{tabular}{|c|c|}
\hline Meas. & Model \\
\hline Hour & Hour \\
\hline
\end{tabular}

Treadway Bridge

Tyler Bridge

$\begin{array}{rr}2.25 & 2.27 \\ 5.50 & 4.11 \\ 14.00 & 10.71 \\ 19.00 & 18.85\end{array}$

Road C

1
-25
-24
-1

Peak Concentration Meas. Model \% Error $\mathrm{ppb} \quad \mathrm{ppb}$

$\begin{array}{lll}493.30 & 77.94 & -84\end{array}$

$\begin{array}{lll}60.84 & 55.82 & -8\end{array}$

$14.26 \quad 16.40$

15

$10.53 \quad 11.37$

8

Table 5

Model Comparison for the 1996 Upper Three Runs Dye Study

$\underline{\text { Sample Location }}$

\begin{tabular}{ccc}
\multicolumn{2}{c}{ Peak Concentration Travel Time } \\
Meas. & Model \% Error \\
Hour & Hour
\end{tabular}

Road C

Highway 125

Box Landing

Mouth

$\begin{array}{rrr}0.35 & 0.73 & 109 \\ 7.75 & 12.10 & 56 \\ 13.00 & 15.01 & 15 \\ 13.50 & 19.47 & 44\end{array}$

Peak Concentration Meas. Model \% Error ppb ppb

$\begin{array}{rrr}897.28 & 49.30 & -95 \\ 59.08 & 13.09 & -78 \\ 44.81 & 11.78 & -74 \\ 47.35 & 10.25 & -78\end{array}$


Figure 1

Dye Sampling Locations for 1995 and 1996 Dye Tracer Studies

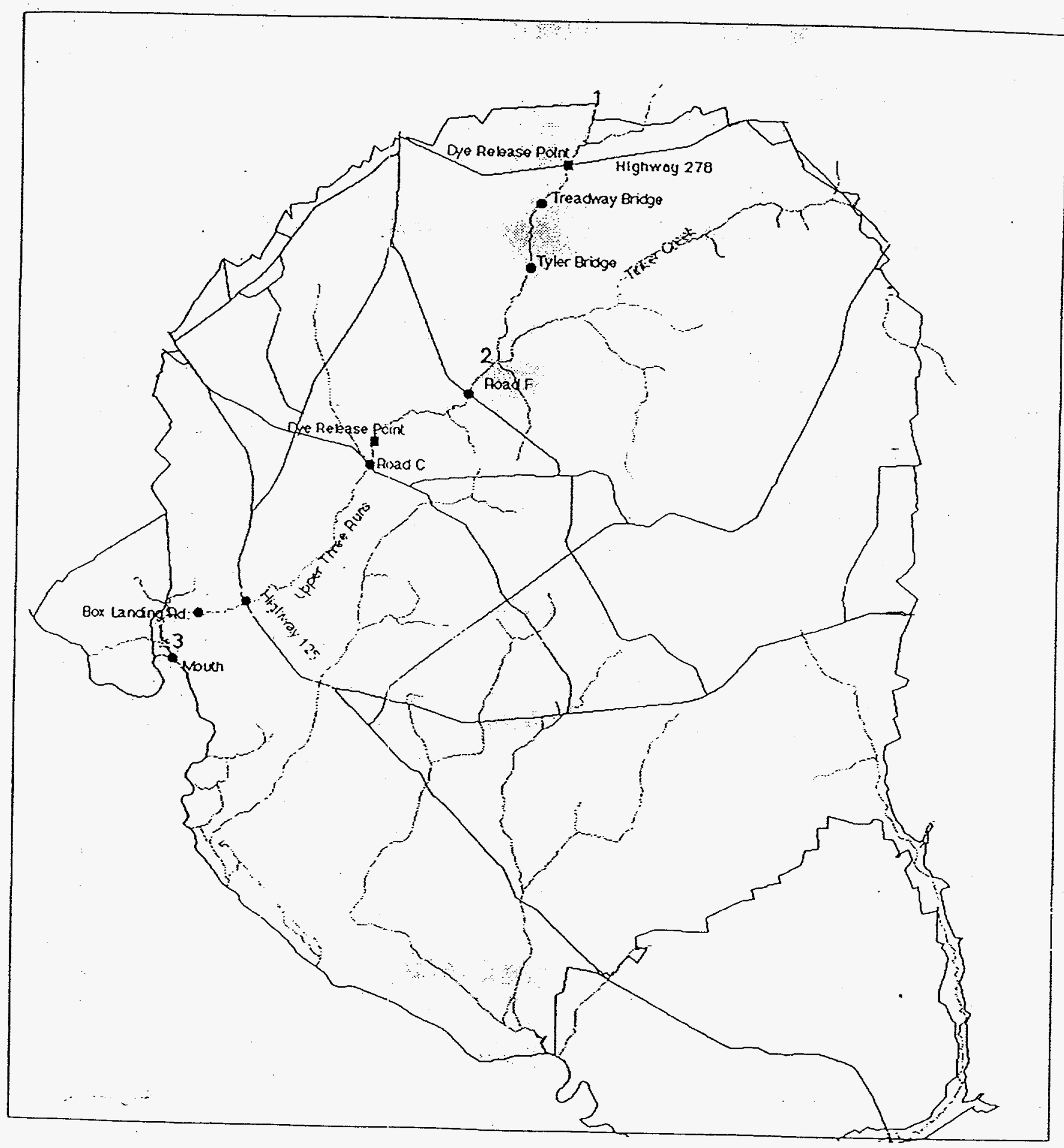


Figure 2

Model Schematics (not to scale)

Upper Three: Runs Flow

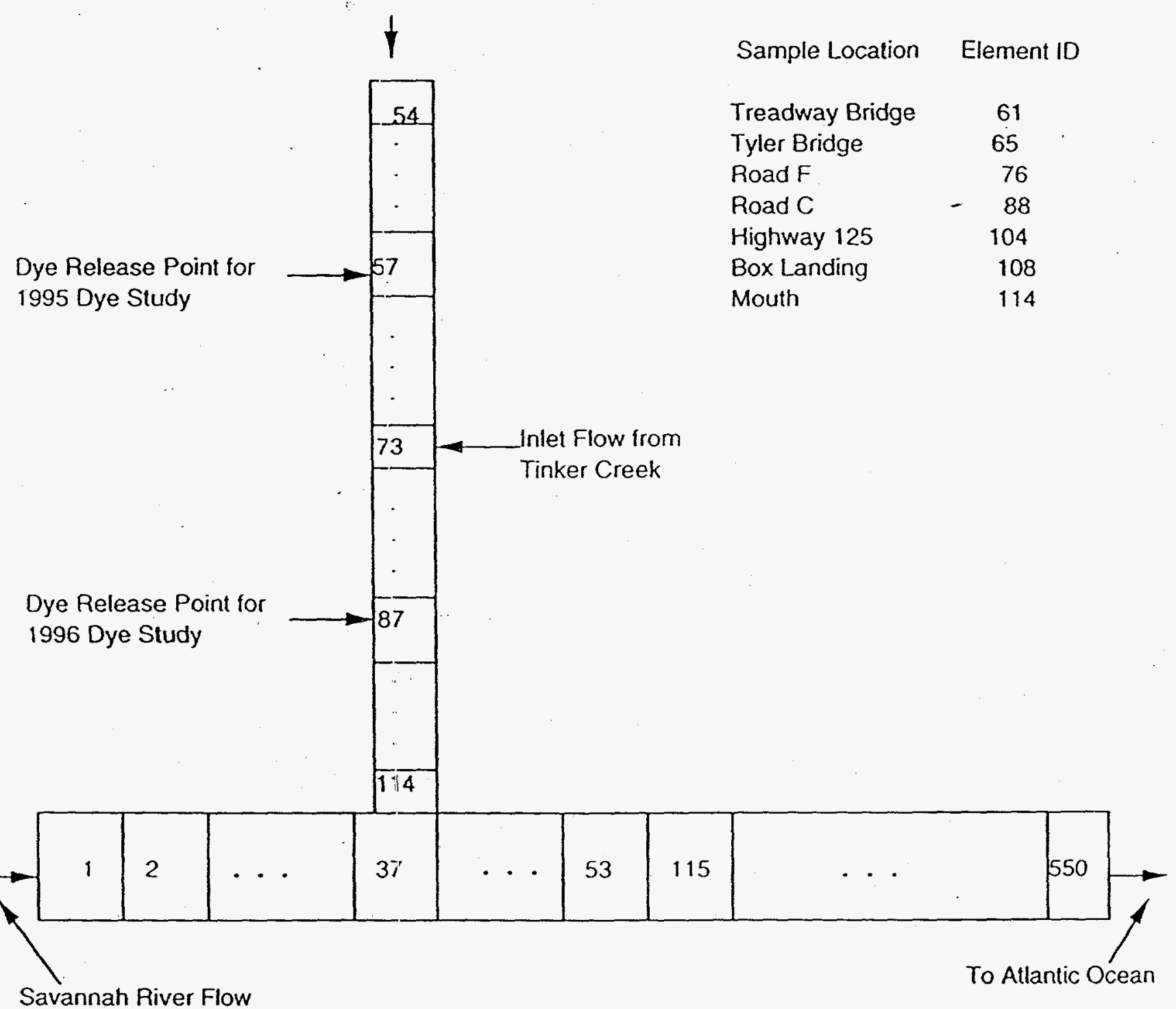


Figure 3

Model Simulation for 1995 Upper Three Runs Dye Study

(Dye Concentrations at Road 8.1)

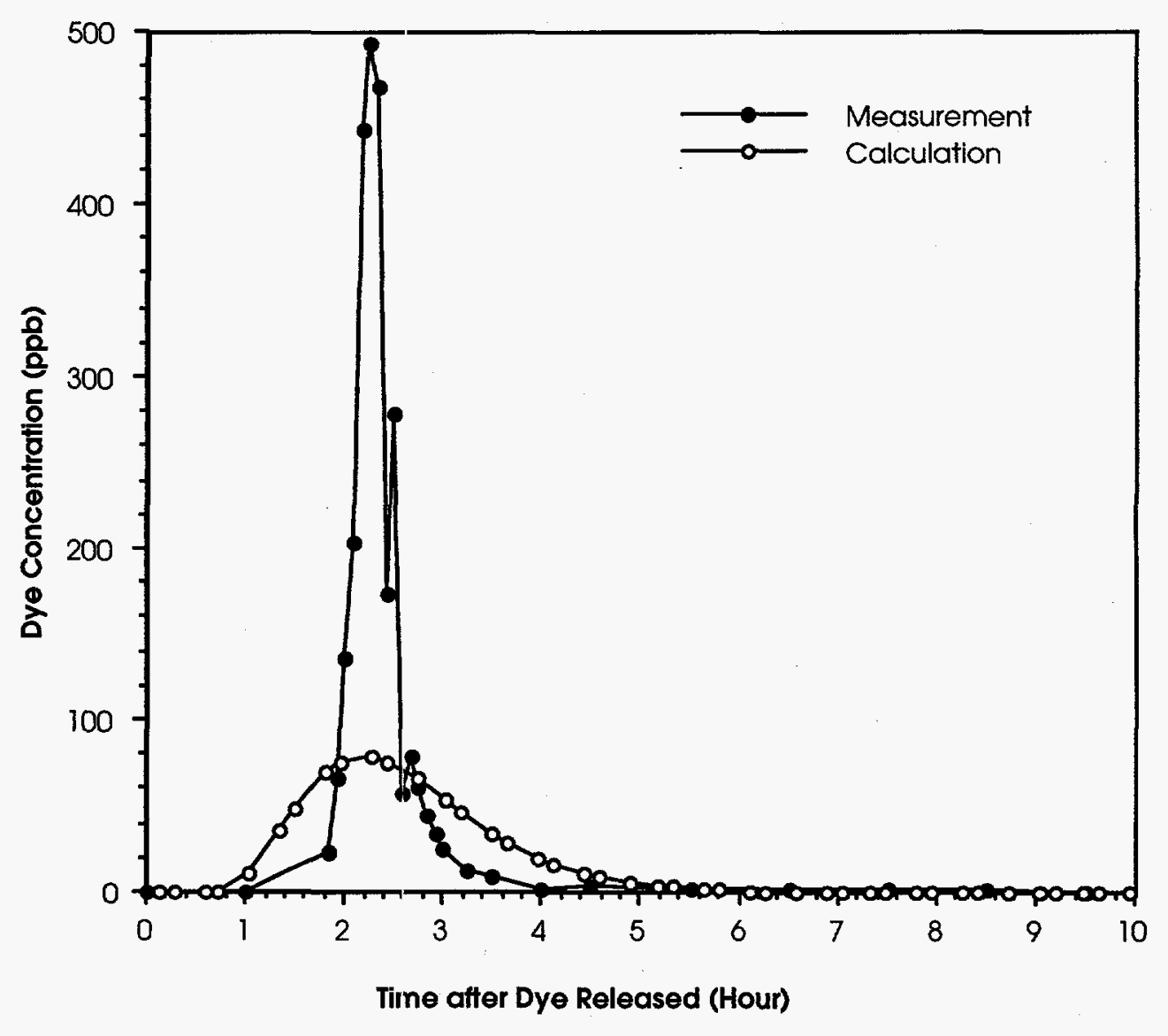


Figure 4

Model Simulation for 1995 Upper Three Runs Dye Study

(Dye Concentrations at Road 2.1)

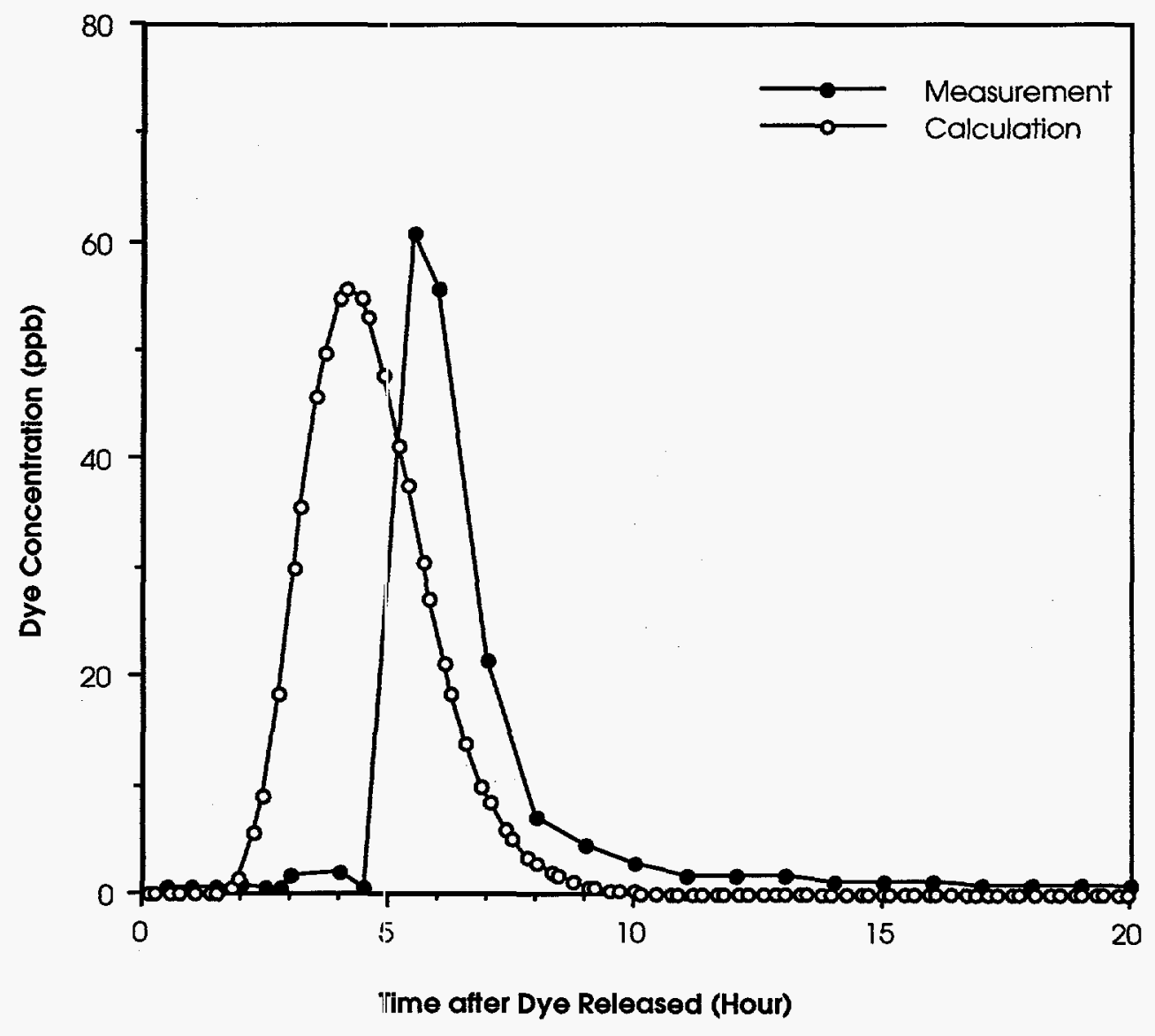


Figure 5

Model Simulation for 1995 Upper Three Runs Dye Study

(Dye Concentrations at Road F)

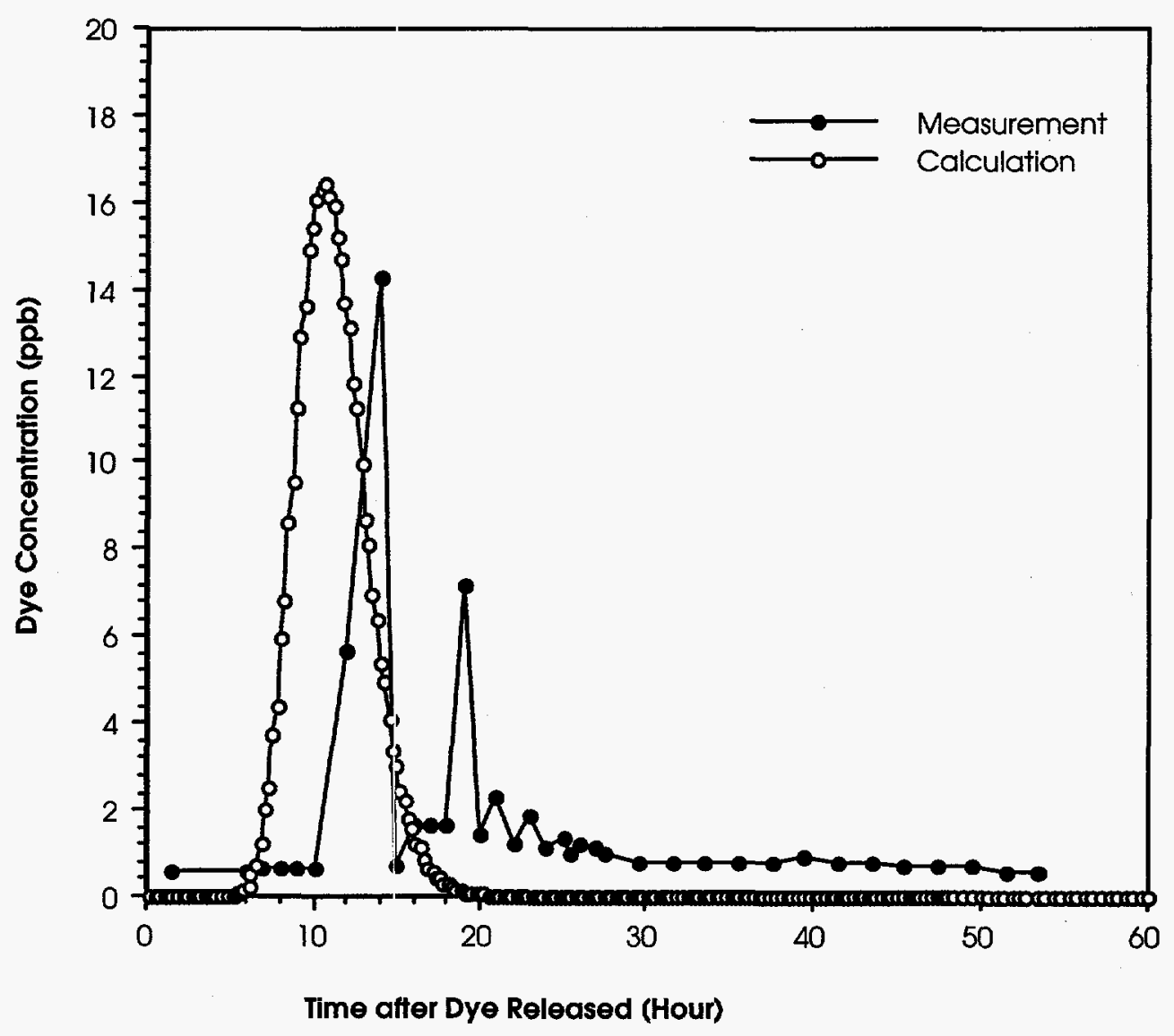


Figure 6

Model Simulation for 1995 Upper Three Runs Dye Study

(Lye Concentrations at Road C)

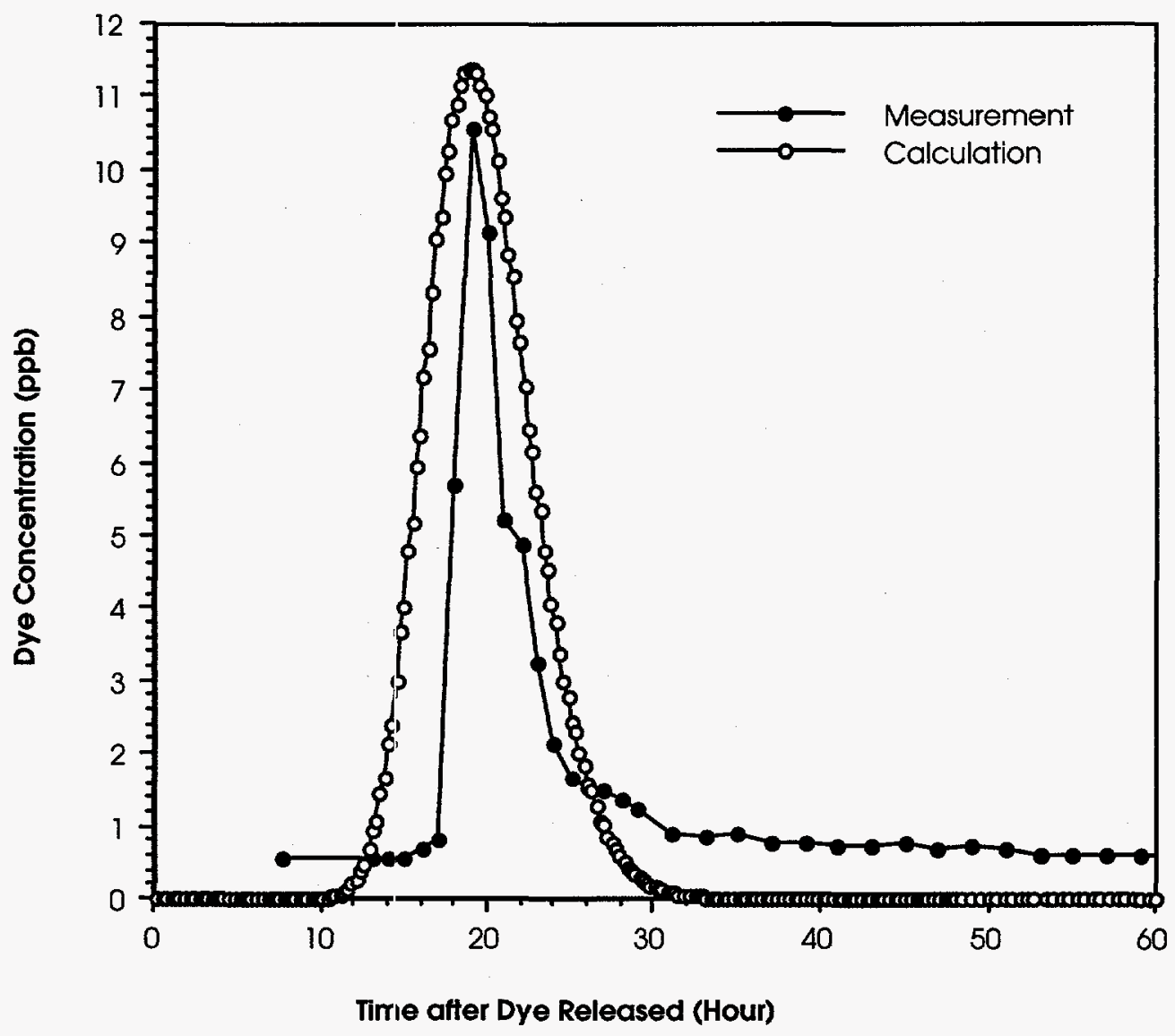


Figure 7

Model Simulation for 1996 Upper Three Runs Dye Tracer Study

(Dye Concentration at Road C)

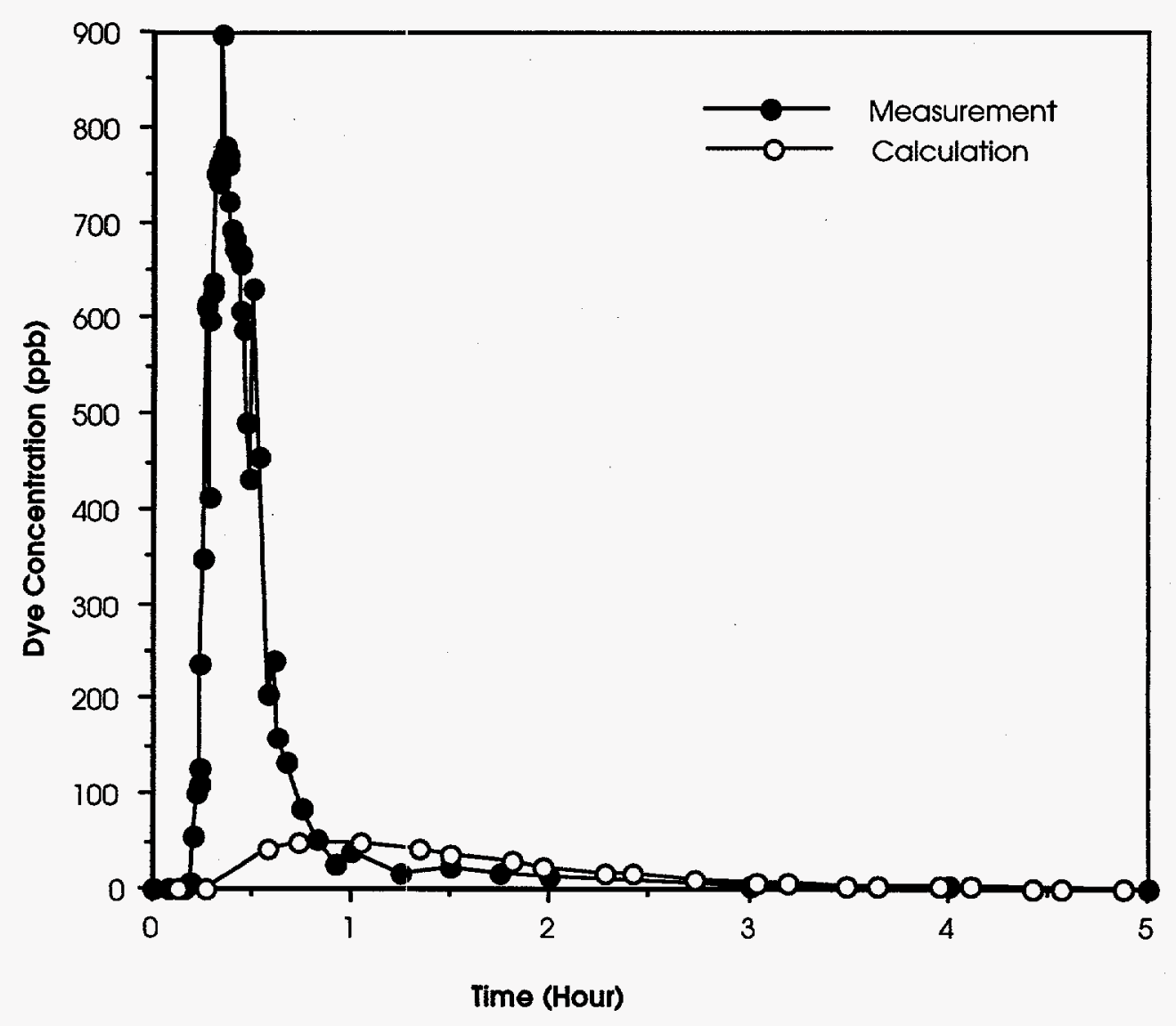


Figure 8

Model Simulation for 1996 Upper Three Runs Dye Tracer Study

(Dye Concentration at Highway 125)

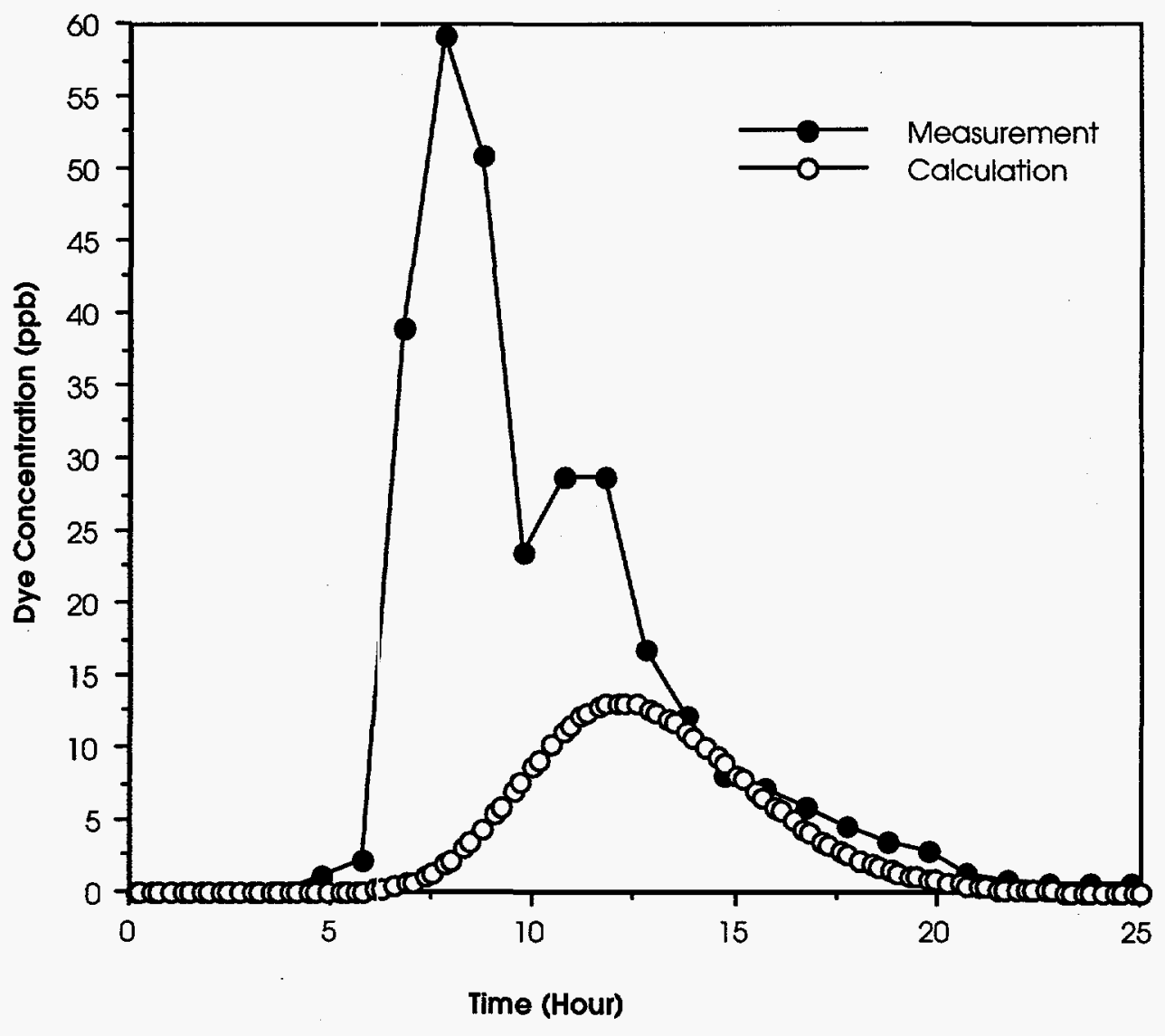


Figure 9

Model Simulation for 1996 Upper Three Runs Dye Tracer Study

(Dye Concentration at Box Landing)

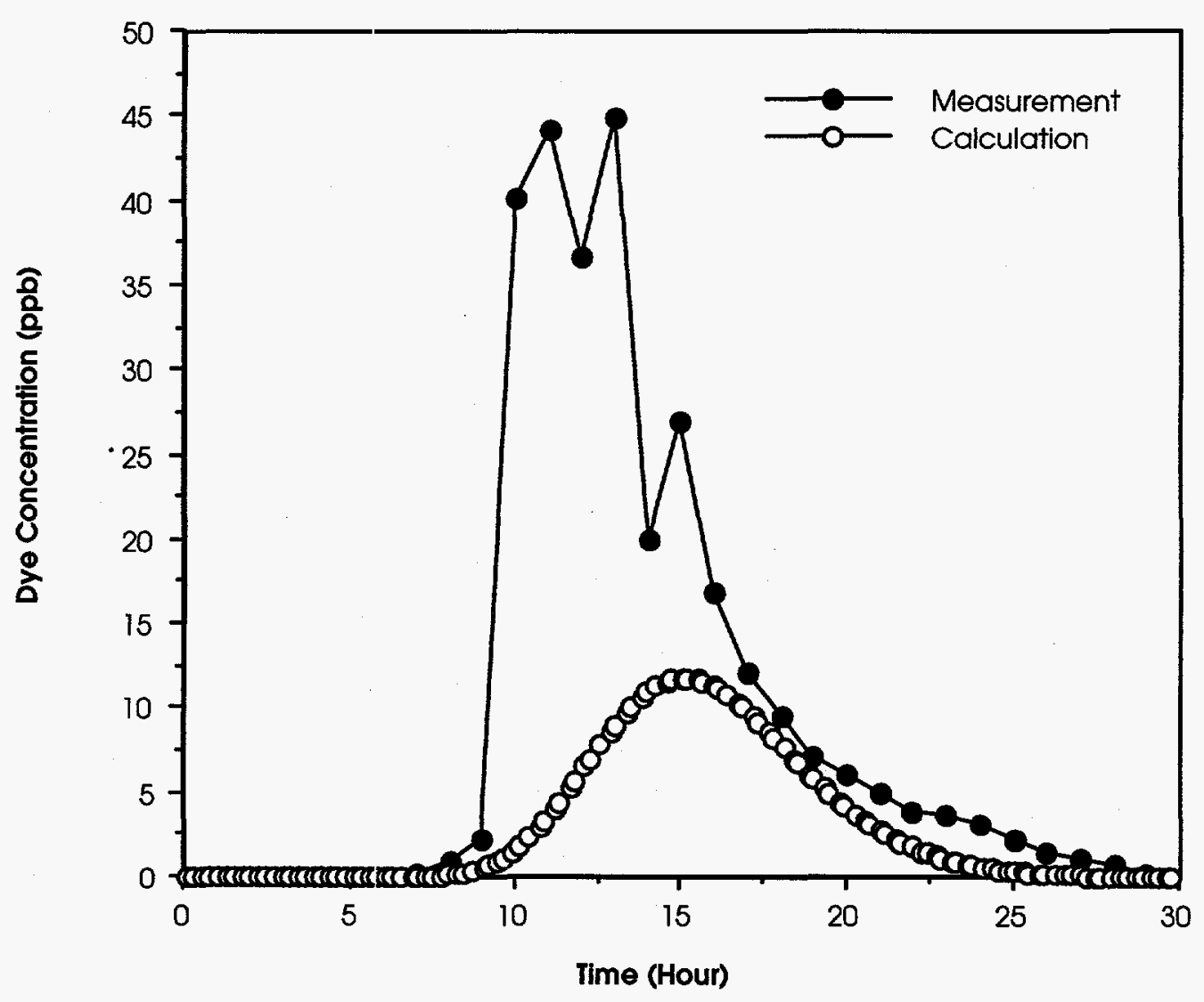


Figure 10

Model Simulation for 1996 Upper Three Runs Dye Tracer Study

(Dye Concentration at Mouth)

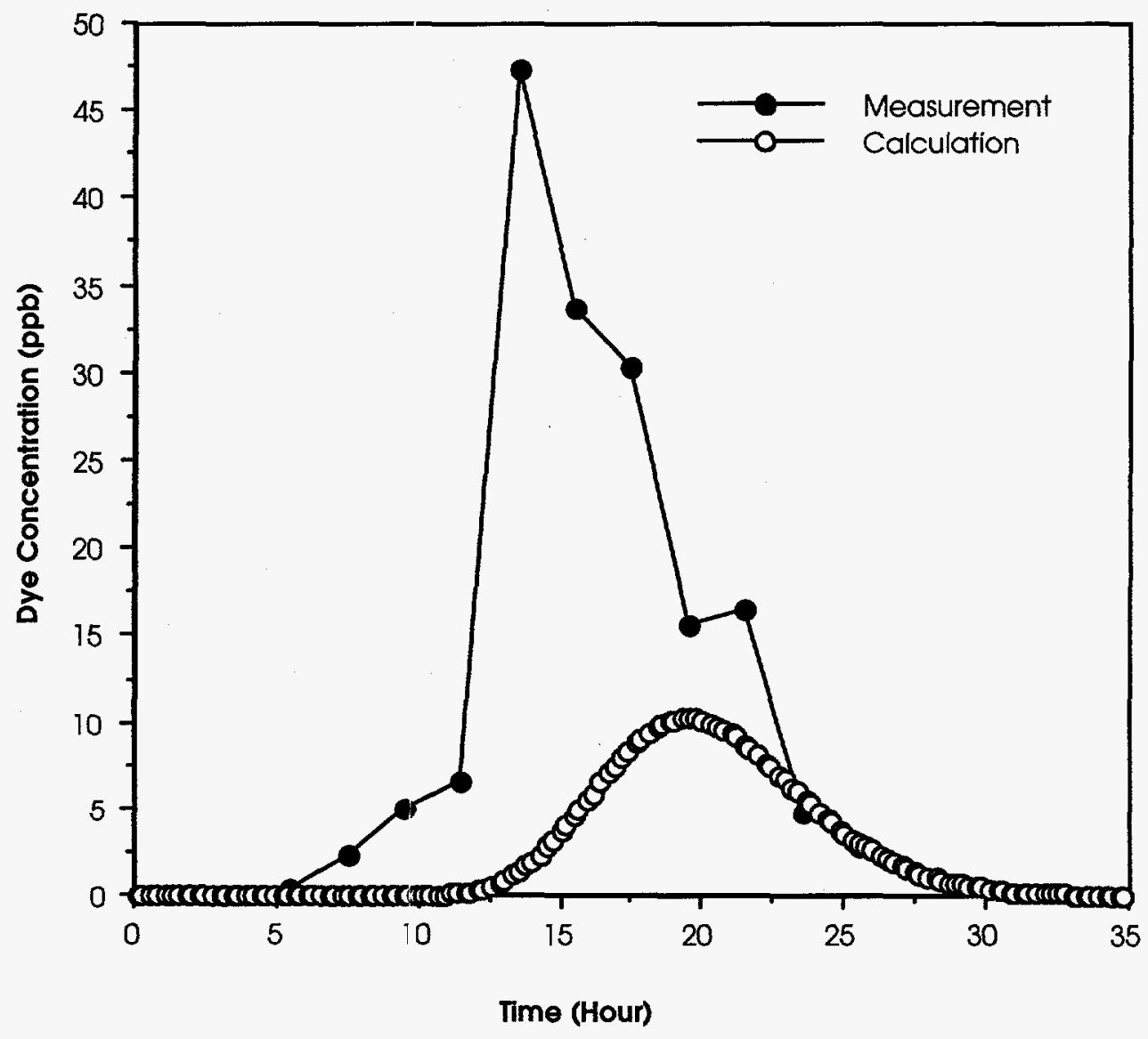


WSRC-TR-98-00225

June 1998

WESTINGHOUSE SAVANNAH RIVER CO.

Report WSRC-TR-98-00225

DISTRIBUTION

SAVANNAH RIVER SITE
A. L. Boni, 773-A
R. P. Addis, 773-A
D. P. Griggs, 773-A
Kuo-Fu Chen, 773-A
SRTC Records (4), 773-52A
NTS Records (5), 773-A 